\section{Literaturoznawstwo służebne}

Justyna Tabaszewska

TEKSTY DRUGIE 2017, NR 1, S. 262-273

DOI: $10.18318 /$ td.2017.1.22
Badania zostały sfi-

nansowane ze środków Narodowego Centrum Nauki przyznanych w ramach finansowania stażu po uzyskaniu stopnia naukowego doktora na podstawie decyzji numer DEC-2014/12/S/HS2/00079.

\section{Uwagi wstępne}

Literaturoznawstwo, tak jak i większość dyscyplin naukowych wchodzących w skład szeroko pojętej, a niecieszącej się ostatnio najlepszą prasą humanistyki, stoi przed piętrzącymi się wyzwaniami. Próba diagnozowania, czym ma być - i jakie ma być - literaturoznawstwo, zmienia się coraz częściej w pytanie o nieco bardziej dramatycznym wydźwięku: jakie literaturoznawstwo jest w stanie uprawomocnić swoje istnienie, wytworzyć - lub odtworzyć - na tyle silną pozycję, by przetrwać i nie stać się zupełnie martwą, kultywowaną tylko od czasu do czasu i z obowiązku dziedziną nauki?

Dramatyzm tego pytania wybrzmiewa tym mocniej, jeśli uświadomimy sobie, że kiedy podobny problem był dyskutowany na początku lat 2000 (czego dowodem może być m.in. antologia tekstów Sporne ibezsporne problemy wspótczesnej wiedzy o literaturze) ${ }^{1}$, to przybierał on formę pytania o to, co zrobić z dynamicznie zmieniającym się

1 Sporne i bezsporne problemy współczesnej wiedzy o literaturze, red. R. Nycz, W. Bolecki, Wydawnictwo IBL PAN, Warszawa 2002.

\section{Justyna}

Tabaszewska - dok-

tor nauk humani-

stycznych, autorka

książek/edna przyroda

czy przyrody alterna-

tywne? O pojmowaniu

i obrazach przyrody

w polskiej poezji

i Poetyki pamięci.

Współczesna poezja

wobec tradycji i pamię-

ci oraz artykułów

publikowanych m.in.

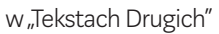

i„Przeglądzie Kulturoznawczym". Aktualnie pracuje w Instytucie Badań Literackich nad projektem „Afektywne poetyki pamięci. Polska literatura i kultura wobec przełomu roku 1989." Kontakt: justyna. tabaszewska@ uj.edu.pl 
literaturoznawstwem. Były to więc wątpliwości dotyczące tego, jaki kierunek rozwoju jest pożądany, jaki daje najlepsze perspektywy rozwoju, a nie jaki może dać przetrwanie.

Wyzwania, przed którymi stoi literaturoznawstwo teraz, nie ograniczają się już do określenia, czy powinno ono pozostać względnie autonomiczne i jednolite metodologicznie. Zamiast tego pojawiły się dwa rodzaje problemów, które można by, ogólnie rzecz ujmując, określić jako wewnętrzne i zewnętrzne. Pierwsze dotyczą tożsamości badań nad literaturą w sytuacji coraz większej ekspansji nowych subdyscyplin naukowych skupionych wokół szeroko rozumianych studiów kulturowych oraz otwierania się na nauki inne niż humanistyczne. W drugim zaś przypadku problemy literaturoznawstwa wynikają wprost z kłopotów humanistyki jako takiej, coraz śmielej krytykowanej za nieprzystawanie do współcześnie preferowanego modelu nauki.

Oba te typy wyzwań i związane z nimi niewątpliwe problemy są ściśle skorelowane z zachodzącymi w Polsce zmianami w funkcjonowaniu oraz finansowaniu nauki, a w szczególności uniwersytetów. Rozwijający się system grantowy miał rozwiązać wszystkie problemy: i te, które dzięki wprowadzeniu konkurencyjności przy pozyskiwaniu dodatkowych środków na prowadzenie badań rozwiązać się da, i te, których nijak w ten sposób rozwiązać się nie da. Przyniósł on polskiej nauce wiele dobrego, ale doprowadził także do zażartej konkurencji między poszczególnymi dyscyplinami, konkurencji, do której w tej formie nigdy nie powinno dojść.

\section{Kłopoty humanistyki problemami literaturoznawstwa}

Obecna krytyka humanistyki przypomina dobrze znane pozytywistyczne zarzuty wobec tego wszystkiego, co nie wpisuje się w jasny model funkcjonowania nauk ścisłych. Dawniejszą formą samoobrony przed takimi zarzutami był przełom antypozytywistyczny z jego silnym przekazem o wartości tych wszystkich badań, które wcale niekoniecznie są powtarzalne i nie zawsze intersubiektywnie komunikowalne, ale wciąż wiele mówią o nas samych oraz otaczającym nas świecie. Pomysł Wilhelma Windelbanda, wspierany i kontynuowany przez Heinricha Rickerta, który sprowadzał się do rozdzielenia nauk nomotetycznych i idiograficznych przy równoczesnym dowartościowaniu tych ostatnich działał jednak - jak już wiemy - tylko przez jakiś czas. Tak jak tylko przez jakiś czas koncepcje Wilhelma Diltheya czy Henri Bergsona 
uprawomocniały zręby przełomu antypozytywistycznego i dostarczały argumentów na rzecz holistycznego rozumienia funkcji humanistyki oraz jej poszczególnych dyscyplin. Przełom ten był także - co okazało się dopiero po pewnym czasie - wyłomem w koncepcjach czegoś, co z braku lepszego określenia można nazwać „nauką czystą”. Odtąd nauka zaczynała mieć także inne, społeczne obowiązki.

Ta zmiana, początkowo dla humanistyki jak najbardziej pożyteczna, z czasem stała się dodatkową komplikacją w jej i tak niepewnym statusie. Jakakolwiek nauka, by zyskać aprobatę oraz finansowanie, jest teraz równocześnie rozliczana ze swej - w różny sposób rozumianej - naukowości oraz użyteczności (a fakt, że te dwie cechy nie muszą być ze sobą związane, dość często w publicznych dyskusjach po prostu umyka). To zaś sprawia, że - paradoksalnie - kiedyś sytuacja była łatwiejsza: poszczególne kierunki czy dyscypliny rozliczano wyłącznie z ich naukowości. Dzięki temu każda dziedzina humanistyki o ugruntowanej metodologii i jasno określonym przedmiocie badań miała przynajmniej podstawowe narzędzia do obrony swojego dobrego imienia.

Próba tego rodzaju uzasadnienia naukowej użyteczności literaturoznawstwa w Polsce przyczyniła się do jego postępującego - w okresie przed licznymi przełomami (a zwłaszcza kulturowym) - zamknięcia. Nadmierne chronienie jedności i unikalności literaturoznawstwa było o tyle niebezpieczne, że zamiast stopniowej ewolucji dochodziło niekiedy do rewolucji, w której poszczególne mody metodologiczne zaczynały rządzić praktycznie całą dyscypliną. Równocześnie, wraz z rozluźnieniem granic między poszczególnymi dziedzinami, literaturoznawstwo - z początku w sposób prawie niezauważalny - zaczęło korodować, rozpuszczać się w kolejnych dyskursach.

Pod tym względem literaturoznawstwo płaciło tę samą, wysoką cenę za próbę odnalezienia się w nowej i nowoczesnej nauce, co cała humanistyka, od której zaczęto nagle wymagać już nie tylko naukowości, ale i użyteczności, najlepiej nie tylko społecznej. W tych poszukiwaniach literaturoznawstwo, niejako „z natury" bardziej oddalone od nauk społecznych niż socjologia czy psychologia, jest w szczególnie trudnej pozycji. Jak bowiem można współcześnie uzasadnić chęć utrzymania dyscypliny naukowej, której głównym celem jest interpretowanie tekstów, choćby i najszerzej rozumianych? Jak znaleźć dla literaturoznawstwa miejsce w coraz bardziej zagrożonej humanistyce i jak zorientować je wobec innych nauk? Czy lepsza jest walka o autonomię, czy negocjowanie sojuszy? 


\section{Między teoriami}

By spróbować odpowiedzieć na te pytania, warto moim zdaniem nieco przeformułować tezę o kryzysie humanistyki. Jak zauważa chociażby Paul Jay w swej niedawno wydanej książce The Humanities "Crisis" and The Future of Literary Studies ${ }^{2}$, wyzwania, przed jakimi stoi humanistyka, wcale nie mają charakteru kryzysu: są stałe, a wątpliwości i zarzuty wobec nauk humanistycznych powtarzają się od dziesięcioleci. Pytanie o praktyczną użyteczność dokonań, tak jak i konflikt między nauką rozumianą jako opowiadającą się za bezwzględną wartością wiedzy oraz wartościującą tę wiedzę ze względu na jej potencjalną użyteczność, są zdaniem Jaya mniej więcej stałe. Takie przedefiniowanie zjawiska określanego jako „kryzys” humanistyki każe inaczej patrzeć na wyzwania między innymi literaturoznawstwa. Podważa ono bowiem pojawiającą się od czasu do czasu sugestię, że obecna sytuacja wynika z faktu, że prawdziwa nauka dynamicznie się rozwija, tymczasem humanistyka stoi w miejscu.

Niemniej, jak wskazuje m.in. Jay, przed literaturoznawstwem stoją co najmniej dwie potrzeby i dwa wyzwania, które trzeba pogodzić: z jednej strony coraz wyraźniej widoczna jest potrzeba mówienia o literaturze jako o części szerszej, kulturowej i społecznej całości, z drugiej tym silniej zarysowuje się konieczność zachowania autonomii badań nad literaturą i wskazania jej wartości. Tym, co jednak przez lata się zmieniało, była powolna utrata uprzywilejowanej pozycji literaturoznawstwa. Przez długi czas literaturoznawstwo było swoistą awangardą metodologiczną, wyznaczającą pola nowych problemów teoretycznych i narzędzia ich badania, teraz jednak ta pozycja bywa coraz częściej zagrożona.

Jeszcze do lat 70. literaturoznawstwo było pod tym względem w wyjątkowo korzystnej sytuacji: nawet gdy tworzono nowe dyskursy czy dyscypliny badawcze, to opierały się one albo na narzędziach badawczych wypracowanych w obrębie nauki o literaturze (jak w przypadku początków filmoznawstwa czy badań narratologicznych), albo - przynajmniej mogły się one także do literaturoznawstwa stosować. Literaturoznawstwo było więc polem szeroko rozumianej wymiany pojęć i koncepcji, którą dobrze opisuje metafora „wędrowania pojęć”, stosowana przez Mieke Bal".

2 P. Jay The Humanities "Crisis" and The Future of Literary Studies, Palgrave Macmillan, Basingstoke 2014, s. 7-33.

3 M. Bal Travelling Concepts in the Humanities. A Rough Guide, University of Toronto Press, Toronto 2002 . 
Zjawisko to, rozumiane jako stopniowe przechodzenie pojęć z jednej nauki do drugiej, skorelowane $\mathrm{z}$ ich powolną ewolucją, było odpowiedzialne z jednej strony za tworzenie pewnej, wspólnej przestrzeni, w obrębie której humaniści mogli prowadzić badania inter-, a później i transdyscyplinarne, z drugiej jednak przyczyniło się także do stopniowego rozsadzania granic między poszczególnymi dyscyplinami i metodologiami.

Ta sytuacja jednak - w toku licznych „zwrotów” - zmieniła się i nic nie zapowiada, by miała szybko wrócić do normy. Literaturoznawstwo staje się miejscem szeroko pojętej negocjacji: negocjowane są i problemy, którym warto poświęcać uwagę, i tryby ich postrzegania oraz opisywania, i wreszcie relacje, jakie ta dyscyplina badawcza nawiązuje z innymi. Coraz częściej - to stanowisko i mnie jest bliskie - uznajemy, że literatura jest autonomicznym, ale jednak jednym z fenomenów kulturowych, a jej badanie z konieczności wymaga pozostawania otwartym na wpływy innych metodologii. Wszelkie próby badania literatury jako dziedziny, która jest uwikłana w wieloznaczne i wielowarstwowe relacje ze światem pozaliterackim oraz pozatekstowym, są równocześnie obiecujące i zagrażające. Obiecujące, gdyż często pozwalają powiedzieć więcej, niż wcześniej było możliwe, zagrażające, gdyż nierzadko literatura staje się w nim nie samodzielnym przedmiotem badania, a jedynie przykładem jakiejś tezy. Na owo niebezpieczeństwo zwracał uwagę również Ryszard Nycz, znany przecież z raczej pozytywnego stosunku do otwarcia badań nad literaturą na wyzwania charakterystyczne dla badań nad kulturą, wskazując, że to tekst powinien znajdować się w centrum naszego zainteresowania, a wcale niekoniecznie określona teoria czy moda metodologiczna:

Praca nad tekstem - ta koronna konkurencja literaturoznawczej profesji - to zarazem praca z tekstem i praca tekstem. Czynność ostatnia jest kluczowa i, w moim przekonaniu, specyficzna dla działalności humanistycznej. [...] Tekst jest w pracy humanistycznej jednocześnie obiektem, partnerem i przewodnikiem... ${ }^{4}$

Pod tym względem wyzwaniem - w pozytywnym rozumieniu tego słowa - są metodologie zorientowane na problem, a nie na konkretną dyscyplinę badawczą (jak badania nad pamięcią, ekokrytyka, badania nad afektem, traumą, doświadczeniem itd.). Są one - jak zauważa m.in. wzmiankowany już

4 R. Nycz Poetyka doświadczenia. Teoria-nowoczesność - literatura, Wydawnictwo IBL PAN, Warszawa 2012, s. 10. 
wcześniej Jay - przykładem otwarcia dyscypliny na konieczność specyficznie pojętego zaangażowania, w którym poszczególne teorie i metodologie wywodzące się z humanistyki służą także analizie pozatekstowych problemów.

Takie ich użycie czyni zadość zarówno postulatowi autonomii określonej dziedziny badań, jak i jej zaangażowania. Ponadto, jak twierdzi Jay, ten rodzaj zaangażowania humanistyki nie jest przecież niczym nowym, nie jest też czymś, co ograniczałoby możliwości jej rozwoju lub rugowało teksty z pierwszej linii zainteresowań literaturoznawcy.

Tezy Jaya, które przytaczałam, stanowią istotny głos w dyskusji o humanistyce zaangażowanej, dyskusji, która wydaje się mieć teraz bardzo duże znaczenie. Stale odnawiający się konflikt między humanistyką autonomiczną a zaangażowaną może być bowiem - choćby dla literaturoznawstwa - nie destrukcyjny, lecz wbrew pozorom i użyteczny, i odświeżający.

\section{Humanistyka - zaangażowana czy autonomiczna?}

Nie tak dawno odbyła się ważna i potrzebna polskiej humanistyce, a zwłaszcza literaturoznawstwu oraz studiom kulturowym, dyskusja nad książką Michała Pawła Markowskiego Polityka wrażliwości. Wprowadzenie do humanistyki ${ }^{5}$. Kolejna książka szeroko znanego polskiego badacza została szybko skrytykowana przez także cieszącego się zasłużonym uznaniem Jana Sowę, który w swym opublikowanym na łamach „Tekstów Drugich” artykule wyraźnie dał do zrozumienia, że ta wizja humanistyki, jaką proponuje Markowski, zupełnie mu nie odpowiada.

Spory między naukowcami, zwłaszcza jeśli mają w tle zarówno lekki konflikt pokoleniowy, jak i odmienne nastawienie badaczy, nie są niczym nadzwyczajnym, nawet gdy - jak ten - przybierają formę dość zażartej polemiki. Istotniejsze jest jednak to - i dlatego do tego sporu się odwołuję - że Markowski i Sowa stoją na dwóch różnych, skrajnie od siebie oddalonych pozycjach. Pierwszą z nich można by z grubsza określić jako poparcie dla humanistyki autonomicznej, drugą zaś dla humanistyki zaangażowanej. Obie te wizje ścierają się w polskich dyskusjach nad przyszłością humanistyki nie pierwszy raz, niemniej to starcie jest wyjątkowo obrazowe.

By lepiej zrozumieć, co mam na myśli, mówiąc o obrazowości owego konfliktu, warto zacytować fragment polemiki Sowy, opublikowanej - wraz

5 M.P. Markowski Polityka wrażliwości. Wprowadzenie do humanistyki, Universitas, Kraków 2013. 
z odpowiedzią Markowskiego, do której jeszcze wrócę - w „Tekstach Drugich” w 2014 roku:

Problem z książką Markowskiego polega raczej na tym, że przez ostatnie dwadzieścia lat zmienił się świat, a wraz z nim humanistyka, natomiast Michał Paweł Markowski po raz kolejny powtarza diagnozę, którą stawiał już wielokrotnie i która od książek o Derridzie i Nietzschem zasadniczo się nie zmieniła. Sprowadzić ją można do postulatu rozbudowy interpretacji świata - a wraz z nią interpretacji literatury i życia - przez mnożenie kontekstów, wymiarów i perspektyw teoretycznych gwarantujących - ponoć - lepsze uchwycenie sensu zarówno własnego doświadczenia życiowego, jak i otaczającej nas rzeczywistości kulturowej. Na tym ma zasadniczo polegać owa „dyskursywna wrażliwość".

Sowa krytykuje książkę Markowskiego z kilku niezależnych powodów. Niezmienność tez i koncepcji autora Polityki wrażliwości jest tylko jednym z nich. Drugim, ważniejszym, jest to, że dawny mistrz mówi do już nie swojego ucznia w języku, którego ten nie akceptuje. A to dlatego, że język ten jest - oczywiście sporo upraszczając - językiem nienastawionym na kontakt. To raczej język sztuki:

Markowski [...] artykułuje w ten sposób swój program, który jest w zasadzie pomysłem na uprawianie sztuki, a nie na tworzenie wiedzy. [...] Cały sens i wartość uprawiania teorii/filozofii/humanistyki polega na tym, że jest nieredukowalna ani do nauk ścisłych, ani do twórczości artystycznej.․

Jan Sowa, występując przeciwko propozycji Markowskiego, występuje także - w swoim rozumieniu - w obronie autonomii humanistyki. Owa autonomia nie jest jednak definiowana jako wyzwolenie ze społecznych obowiązków, lecz jako zachowanie osobności oraz odrębności humanistyki jako nauki o potencjale społecznego wpływu właśnie. Protest Sowy wobec zrównywania humanistyki i sztuki jest oczywiście zrozumiały. Z postulatem odróżnienia specyficznych zadań humanistyki niełatwo się nie zgodzić. Jednak kiedy badacz przedstawia coś, co można by określić jako pozytywny program, robi się trochę trudniej:

6 J. Sowa Humanistyka płaskiego świata, "Teksty Drugie” 2014 nr 1, s. 193-194.

7 Tamże, s. 204. 
Zadanie, które ma dzisiaj do spełnienia humanistyka, i sens jej istnienia polega na dopilnowaniu, aby ruch dialektycznej śruby mógł wykonać swój pełny obrót, czyli żeby wyalienowane efekty działalności człowieka przestały sprawować nad nim władzę i zamiast tego stały się środkami jego (i jej!) emancypacji. ${ }^{8}$

Oczywiście Sowa, opisując zadanie, jakie stoi przed współczesną humanistyką, posługuje się specyficznym językiem, którego metaforyka jest uwikłana w tradycje filozofii krytycznej. Tym jednak, co mnie osobiście przeszkadza, nie jest wcale pewna metaforyczność tego fragmentu, lecz jego niekonkretność. Przekonanie, że teoria zmienia praktykę i konkretne działania podejmowane w obrębie działalności naukowej przekładają się na określone, pozytywne skutki społeczne, może być słuszne, ale nie za wiele mówi o tym, jaką humanistykę powinno się projektować i z czego rozliczać.

Te wątpliwości, o których przed momentem wzmiankowałam, posłużyły też za punkt wyjścia dla polemiki, jaką z krytyką Sowy podejmuje Markowski. Autor Polityki wrażliwości na zarzut - kierowany wobec jego teorii - niezaangażowania społecznego humanistyki oraz zrównania jej ze sztuką odpowiada, wytaczając argument najcięższego możliwego kalibru, a mianowicie oskarża o naiwność lub cynizm:

Na tym właśnie polega humanistyka, w odróżnieniu od nauk ścisłych: że się wadzimy osobiście, bo są to dla nas, nie dla nauki per se, ważne sprawy. Nie łudźmy się: nikogo poza nami te rzeczy nie obchodzą. Bo my nie robimy nauki, w przeciwieństwie do fizyków i onkologów, tylko opowiadamy swoje własne historie, licząc na to, że ktoś się nimi zainteresuje. ${ }^{9}$

Wizje humanistyki, jakie przedstawiają obaj badacze, są od siebie tak bardzo oddalone nie dlatego, że odmienne definiują oni cele humanistyki, ale - co moim zdaniem w tym sporze najważniejsze - inaczej w ogóle zapatrują się na problem 'celów' humanistyki. Sowa twierdzi, że humanistyka ma swój jasno określony, choć oczywiście czasowo zmienny cel, że da się go wyznaczyć, że da się sprawdzać, czy to, co w ramach humanistyki tworzymy, ma z owym nadrzędnym celem cokolwiek wspólnego. Dla autora Fantomowego

8 Tamże, s. 205.

9 M.P. Markowski Lewica akademicka: między hipokryzją i iluzjq, "Teksty Drugie” 2014 nr 1, s. 209. 
ciała króla tym, co definiuje humanistykę, jest nie tyle jej metodologia czy przedmiot badania, ile cel właśnie. Tymczasem dla Markowskiego humanistyka występuje zawsze jako podzielona ${ }^{10} \mathrm{i}$ odpowiadająca na różne potrzeby działalność raczej twórcza niż naukowa czy teoretyczna. Drugą niemożliwą do przeoczenia różnicą między Sową i Markowskim jest odmienne akcentowanie tego, dla kogo jest humanistyka. Markowski, stwierdzając, że „nikogo poza nami te rzeczy nie obchodzą”, zawęża krąg osób w jakikolwiek sposób humanistyką zainteresowanych do w gruncie rzeczy ograniczonej grupy, trochę tak, jak czynił to w swej instytucjonalnej teorii sztuki Dickie oraz w koncepcji świata sztuki Danto"1. Ten świat jest zdaniem Sowy zdecydowanie za mały: humanistyka ma obowiązki nie tyle wobec tych, którzy w jej obrębie pracują, co wobec tych, którzy są z niej wykluczeni.

Dyskusja Markowskiego i Sowy jest więc w gruncie rzeczy radykalnym sporem o 'zaangażowanie' humanistyki, o zakres jej obowiązków i zależności. Wyostrzone w dyskusji postulaty badaczy ${ }^{12}$ pozwalają moim zdaniem wyraźniej dostrzec istotę owego sporu i zaryzykować - opierając się na koncepcji Jaya - na wytworzenie drogi środka, jaką - moim zdaniem - może być humanistyka służebna.

\section{Humanistyka służebna}

Wprowadzając pojęcie służebności, nie chcę mnożyć teorii czy koncepcji ponad miarę, a jedynie opisać narzucającą się intuicję oraz zaproponować moim zdaniem wcale nie taki zgniły - kompromis. Pojęcie służebności, silnie zakorzenione w naszym języku, odwołuje się także do jednej z lepiej znanych koncepcji prawnych. „Służebność” to określone prawo, które obciąża daną nieruchomość w celu zwiększenia użyteczności innej nieruchomości lub jak w przypadku służebności osobistej - zapewnienia konkretnego prawa

10 Por. M.P. Markowski Lewica akademicka, s. 209: „Humanistyka [...] jest trwale podzielona, różne interesy, różne języki i różne cele jej przyświecają i hołdowanie iluzji, że kiedykolwiek się ona uspójni i nada sens ludzkiemu życiu jako takiemu [...] jest niezwykle naiwne". Por. A. Danto The Artworld „ "The Journal of Philosophy" 1964 LXI, s. 571-584. gdyż ta forma wymusza ostrzejsze i bardziej przejrzyste niż książka formułowanie własnych sądów. 
określonej osobie ${ }^{13}$. Mówiąc nieco inaczej, ustanowienie służebności obciąża określoną rzecz konkretnymi obowiązkami, których niełatwo się pozbyć, które trwają, nawet jeśli dana nieruchomość zmieni właściciela. Służebność wyznacza funkcje pewnego obiektu, odpowiadając na potrzeby nie tylko tych, do których ta rzecz należy.

Podchodząc do tego pojęcia już nieco bardziej metaforycznie, można uznać, że służebność wiąże się z określonymi obowiązkami, lecz nie z całkowitym podporządkowaniem: tak długo, jak to, co jest obciążone obowiązkiem służebności, ów obowiązek wypełnia, może być używane w dowolny sposób. Gdyby spojrzeć na literaturoznawstwo, a szerzej i na humanistykę, jako na dziedzinę nauki, która niesie ze sobą określone obowiązki społeczne, koncepcja służebności mogłaby całkiem nieźle wyjaśnić ich charakter i - przede wszystkim - granice. Najostrzejsza krytyka humanistyki polega na wskazywaniu, że wszystko, co nie jest w niej użyteczne, co nie nadaje się do prostego przełożenia na język korzyści (choćby i społecznych), nie zasługuje na wsparcie i nie powinno istnieć. Tymczasem powinno być dokładnie odwrotnie: jak długo humanistyka w ogólności, a literaturoznawstwo w szczególności, spełnia określone społeczne funkcje, tak długo nie ma podstaw, żeby kwestionować jego użyteczność w ogóle. Pewne służebności są niezbywalne, ale nie ograniczają pola humanistyki, tak jak możliwość praktycznego zastosowania określonych odkryć nie zawęża pola badań tradycyjnie pojmowanych nauk ścisłych.

To, co stanowi o możliwościach literaturoznawstwa służebnego jako projektu, który przecież - jeśliby popatrzeć na deklaracje badaczy zarówno z Polski, jak i spoza niej - funkcjonuje w praktyce już od jakiegoś czasu ${ }^{14}$, jest także dla niego zagrożeniem. Coraz większe otwieranie literaturoznawstwa na nowe potrzeby i modyfikowanie jego języka w taki sposób, by mógł mówić nie tylko o literaturze, ale i o świecie, do którego się ona odnosi, ma także negatywne konsekwencje. Tym, co mnie osobiście w tych w większości pozytywnych zmianach niepokoi, jest pewna tendencja do rozdrobnienia. Nie mówię tu wcale o powstawaniu nowych subdyscyplin, jak visual czy memory studies, lecz o terrorze restrykcyjnie rozumianego case studies.

13 Por. Kodeks cywilny, art. 285-305.

14 Badania nad pamięcią kulturową i społeczną, a także studia nad traumą są uzasadniane - zazwyczaj - właśnie społeczną użytecznością, możliwością zastosowania zdobytej w ich ramach wiedzy do lepszego nie tylko rozumienia, ale i projektowania życia społecznego. 
Literaturoznawstwo, tak jak cała humanistyka, może utrzymać (lub odzyskać, jeśli uznajemy, że już je straciła) ważne miejsce we współczesnym świecie, jeśli będzie badać nie tylko teksty i nie tylko tworzyć teorie, ale także diagnozować istotne problemy społeczne i kulturowe. Kiedy więc piszę o literaturoznawstwie służebnym, to właśnie ten wymiar uznaję za słusznie oczekiwaną i narzucaną przez społeczeństwo służebność na rzecz szerszej wspólnoty niż tylko wspólnota tych, którzy zawodowo czytają i interpretują poszczególne teksty kultury. Oczywiście tak rozumiana służebność może wydawać się mało radykalna, choćby dlatego, że możliwości rozwiązywania wspomnianych problemów są dla teoretyków i badaczy zazwyczaj ograniczone. Myślę jednak, że ich dostrzeganie oraz opisywanie nie jest rzeczą zupełnie trywialną czy mało użyteczną.

Ten cel funkcjonowania literaturoznawstwa i humanistyki jest niezwykle istotny. Niemniej, nie jest wcale jedyny. Diagnozowanie problemów czy uczenie ich dostrzegania musi pozostać nie jedynym, a jednym z celów literaturoznawstwa. Jego funkcja służebna, zarówno wobec społeczeństwa, jak i - nierzadko - wobec innych dyscyplin badawczych nie może być jedyną. Jak każda dyscyplina badawcza, która nie jest martwa, literaturoznawstwo musi szukać dróg dla własnego rozwoju i przez sięganie do korzeni, a więc przez pracę z tekstem, nad tekstem i tekstem, jak chciałby Ryszard Nycz, i przez opowiadanie własnych historii, jak sugerował Michał Paweł Markowski, i przez eksperymenty metodologiczne i przez inspirację innymi, nie tylko humanistycznymi dyscyplinami naukowymi i wreszcie - jak chciałby Jan Sowa - przez zaangażowanie w zmienianie już tego nietekstowego świata.

Projekt humanistyki i literaturoznawstwa służebnego, taki, jakim chciałabym go widzieć, nie spodobałby się raczej ani Markowskiemu, ani Sowie. Zarówno dla jednego, jak i dla drugiego byłby to jednak zgniły kompromis między autonomią rozumianą jako wyzwolenie ze społecznych obowiązków i uzasadnieniem dla jej istnienia czerpanym ze społecznej użyteczności. Ten zgniły kompromis miałby jednak przynajmniej jedną mocną stronę: pozostawiałby dość miejsca dla obu badaczy, szanując i autonomię literatury, i jej obowiązki. Służebność, w tym rozumieniu, które chcę tu przyjąć, nie jest ani pełnym podporządkowaniem zewnętrznym potrzebom, ani zgodą na uznanie całkowitej autoteliczności tej dziedziny nauki. Jest drogą środka, którą spora część z nas idzie, bez względu na to, czy bliżej nam do poglądów Sowy, czy do poglądów Markowskiego. 


\section{Abstract}

\section{Justyna Tabaszewska}

THE INSTITUTE OF LITERARY RESEARCH OF THE POLISH ACADEMY OF SCIENCES (WARSAW)

Servile Literary Studies

Tabaszewska presents the concept of ancillary literary studies within the context of debates on the humanities' function and goals. She proposes to view literary scholarship, and the humanities more broadly, as a sphere in which the autonomy of research projects does not preclude their social engagement. Accordingly, the task of ancillary literary studies would be not only to study texts and create theories, but also to diagnose problems that are relevant to society.

\section{Keywords}

engaged humanities, goals of literary studies, New Humanities, crisis of the humanities 